\title{
Role of sports tourism in the school children health improvement
}

\author{
Ludmila Demyanova ${ }^{1}$, Irina Usova ${ }^{2}$, Arshak Tashchiyan ${ }^{3}$, Nikolai Ryzhkin ${ }^{1}$, and Sergey \\ Demyanov $^{1}$ \\ ${ }^{1}$ Don State Technical University, 344000, Rostov-on-Don, Russia \\ ${ }^{2}$ Institute of Technologies (branch) of DSTU in Volgodonsk, 347386, Volgodonsk, Russia \\ ${ }^{3}$ Rostov Law Institute of the Ministry of Internal Affairs of the Russian Federation, 344015, Rostov- \\ on-Don, Russia
}

\begin{abstract}
The effective use of physical culture and sports means the prevention of diseases, maintaining high working capacity of people, preventing offenses, overcoming drug addiction, bad habits, implementing and ensuring the constitutional guarantee of the right of citizens to equal access to physical education, sports and tourism, and fostering a healthy lifestyle. The basis of this way of life is physical culture and sports, which purposefully, naturally increase the vitality of the systems and functions of the human body. Traveling, hiking, learning new things in the world around them, which includes tourism in all its diversity, play an important role in the formation of a healthy lifestyle and harmonious development of the individual.
\end{abstract}

\section{Introduction}

Tourism (French tourisme, from tour - walk, trip) - travel (trip, hike) in free time (vacation, vacation, etc.); type of active recreation, a means of health improvement, cognition, spiritual and social development of a person [1]. Tourism is life in all its diversity, concentrated on a short period of time, characterized by a certain goal-setting and a way of implementation. Systematic tourism classes are designed to ensure the harmonious development of physical qualities and related abilities, achieving the required level of general physical fitness, taking into account the characteristics of the current period of age development, increasing the degree of hardening of the body, familiarizing with in-depth knowledge of the chosen sport. Currently, every second person in our country either travels or participates in excursions [2]. Pupils and students strive for active recreation. Numerous examples indicate that this particular type of recreation has a beneficial effect on health, the neuro-emotional sphere, and the state of the tourist's mental health. A pedestrian is happier than a passenger; a rich, interesting world opens up to him, which cannot be seen from the window of a passing train or car. It is believed that movement as such can in its action replace any remedy, but all the remedies in the world cannot replace the action of

\footnotetext{
*Corresponding author: irina_usova@mail.ru
} 
movement $[3,4]$. It is widely known that when walking, the body trains, the heart works more energetically, dexterity, coordination of movements develops, the nutrition of working muscles improves, their volume and strength increase, the blood flow in the vessels is accelerated, and the blood is more oxygenated, breathing becomes deeper, and posture improves $[5,6]$. It is with school tourism that we must begin to improve the health improvement of student youth. It is pedestrian tourism in our modern society that can have a huge impact on the upbringing of a schoolchild as a person, harmoniously combining spiritual wealth, moral purity and physical perfection [7].

\section{Sports tourism as a means of health improvement}

The analysis of scientific literature made it possible to identify a contradiction between the existing needs of modern society in the use of physical culture, sports and tourism in improving the somatic, mental and physical health of children and the level of use of sports tourism in solving this problem $[8,9]$.

Therefore, the improvement of sports tourism programs as a factor in improving the somatic, mental and physical health of children is an urgent task of pedagogy [10].

In the study 36 schoolchildren aged 10 to 12 years were involved. Among them there were 24 students engaged in tourist all-around in the Center for Children's Youth Tourism and 12 students of secondary schools.

The study involved three groups:

- control group 1 (CG1) - students of a secondary general education school, engaged in physical education in the volume of the school curriculum, 3 hours a week in the amount of 12 people.

- control group 2 (CG 2) - students engaged in tourism at the Pilgrim Center for Children Youth Tourism according to the standard program.

- the main group (MG) - students engaged in tourism in the Center for Children Youth Tourism according to the developed program for planning the educational material of the tourist all-around.

CG2 and MG are first-year initial training groups (ITG). The parameters of the physical state were determined: running for $100 \mathrm{~m}$ and $1000 \mathrm{~m}$, long jumps from the spot, determination of general working capacity.

After processing the data obtained, it was found that the students involved in the experimental group had low health indicators and, in our opinion, they could not fully master the program. To solve this problem, we have developed an experimental program of educational material on sports tourism, making a bias towards the development of general physical fitness (GPF) and adding 1 hour per week to the standard program. Since the program is designed for 216 hours per year, we have reduced the number of hours devoted to technique and tactics in the tourist all-around (by 20 hours), special physical training (SPT) of an athlete (by 10 hours), topography and the basics of orienteering on the ground (by 4 hours) and increased by 34 hours classes for the development of general physical fitness, which amounted to 74 hours per year.

This, in our opinion, should lead to an improvement in indicators, which, in turn, in the 2nd year of study, will lead to a better assimilation of the program and the achievement of good sports results. A new program for experimental planning of educational material was developed (Table 1).

Table 1. An experimental program of educational material for 10-12 year-old students involved in tourist all-around

\begin{tabular}{|c|c|c|c|c|c|c|c|}
\hline \multirow{2}{*}{$№$} & \multirow{2}{*}{ Theme } & \multicolumn{3}{|c|}{ Standard program } & \multicolumn{3}{|c|}{ Author's program } \\
\cline { 3 - 6 } & & Total & Theory & Practice & Total & Theory & Practice \\
\hline
\end{tabular}




\begin{tabular}{|c|c|c|c|c|c|c|c|}
\hline 1. & $\begin{array}{l}\text { Features of } \\
\text { tourist all- } \\
\text { around }\end{array}$ & 2 & 2 & - & 2 & 2 & - \\
\hline 2. & $\begin{array}{l}\text { Local history } \\
\text { training of an } \\
\text { athlete }\end{array}$ & 6 & 3 & 3 & 6 & 3 & 3 \\
\hline 3. & $\begin{array}{l}\text { Topography and } \\
\text { the basics of } \\
\text { orientation on } \\
\text { the ground }\end{array}$ & 16 & 6 & 10 & 16 & 6 & 10 \\
\hline 4. & $\begin{array}{l}\text { Sanitation and } \\
\text { hygiene rules }\end{array}$ & 8 & 4 & 4 & 8 & 4 & 4 \\
\hline 5. & $\begin{array}{l}\text { Medical } \\
\text { training. } \\
\text { Biomedical } \\
\text { control and self- } \\
\text { control }\end{array}$ & 8 & 4 & 4 & 8 & 4 & 4 \\
\hline 6. & $\begin{array}{c}\text { Moral and } \\
\text { psychological } \\
\text { preparation of } \\
\text { an athlete }\end{array}$ & 6 & 6 & - & 6 & 6 & - \\
\hline 7. & $\begin{array}{l}\text { Life and food of } \\
\text { a tourist. } \\
\text { Protection of } \\
\text { Nature } \\
\end{array}$ & 2 & 1 & 1 & 2 & 1 & 1 \\
\hline 8. & $\begin{array}{l}\text { Personal and } \\
\text { group } \\
\text { equipment of an } \\
\text { athlete } \\
\end{array}$ & 7 & 3 & 4 & 7 & 3 & 4 \\
\hline 9. & $\begin{array}{l}\text { Technique and } \\
\text { tactics in tourist } \\
\text { all-around }\end{array}$ & 55 & 15 & 40 & 55 & 15 & 40 \\
\hline 10. & $\begin{array}{l}\text { Ensuring safety } \\
\text { in tourism }\end{array}$ & 2 & 2 & - & 2 & 2 & - \\
\hline 11. & $\begin{array}{l}\text { General physical } \\
\text { fitness of the } \\
\text { athlete }\end{array}$ & 79 & 2 & 77 & 79 & 2 & 77 \\
\hline 12. & $\begin{array}{l}\text { Special physical } \\
\text { training of an } \\
\text { athlete }\end{array}$ & 25 & 2 & 23 & 25 & 2 & 23 \\
\hline 13. & $\begin{array}{l}\text { Participation in } \\
\text { competitions }\end{array}$ & \multicolumn{3}{|c|}{ off the grid } & \multicolumn{3}{|c|}{ off the grid } \\
\hline 14. & $\begin{array}{l}\text { Summer sports } \\
\text { camps }\end{array}$ & \multicolumn{3}{|c|}{ off the grid } & \multicolumn{3}{|c|}{ off the grid } \\
\hline
\end{tabular}

To assess the effectiveness of the application of the experimental program of initial training in the groups of sports tourism, a study was carried out and the results were summed up, so, the following indicators of the development of physical qualities were established (tables 2-5).

Table 2. Dynamics of changes in the level of physical readiness CG1

\begin{tabular}{|c|c|c|c|c|}
\hline \multirow{2}{*}{ Indicators } & $\begin{array}{c}\text { At the beginning } \\
\text { of the year }\end{array}$ & $\begin{array}{c}\text { At the end of } \\
\text { the year }\end{array}$ & \multirow{2}{*}{$\mathrm{t} 1$} & \multirow{2}{*}{$\mathrm{P} 1$} \\
\cline { 2 - 3 } & $\mathrm{X} \pm \mathrm{x}$ & $\mathrm{X} \pm \mathrm{x}$ & \\
\hline
\end{tabular}




\begin{tabular}{|c|c|c|c|c|}
\hline Running 100 meters & $24.5 \pm 0.8$ & $25.33 \pm 0.75$ & 0.073 & $<0.04$ \\
\hline Running 1000meters & $4.58 \pm 0.23$ & $4.40 \pm 0.2$ & 0.327 & $<0.03$ \\
\hline Long jump from the spot & $172.4 \pm 8.3$ & $174.2 \pm 8.3$ & 1.8 & $<0.05$ \\
\hline Harvardstep-test & $63.5 \pm 1.74$ & $65.0 \pm 1.7$ & 0.396 & $<0.04$ \\
\hline
\end{tabular}

Table 3. Dynamics of changes in the level of physical readiness CG2

\begin{tabular}{|c|c|c|c|c|}
\hline \multirow{2}{*}{ Indicators } & $\begin{array}{c}\text { At the beginning } \\
\text { of the year }\end{array}$ & $\begin{array}{c}\text { At the end of } \\
\text { the year }\end{array}$ & \multirow{2}{*}{ t1 } & P1 \\
\cline { 2 - 3 } & $\mathrm{X} \pm \mathrm{x}$ & $\mathrm{X} \pm \mathrm{x}$ & & \\
\hline Running 100 meters & $25.2 \pm 1.1$ & $24.5 \pm 1.2$ & 0.085 & $<0.04$ \\
\hline Running 1000meters & $5.01 \pm 0.41$ & $4.45 \pm 0.35$ & 0.114 & $<0.03$ \\
\hline Long jump from the spot & $165.9 \pm 2.3$ & $170.7 \pm 2.4$ & 0.182 & $<0.05$ \\
\hline Harvardstep-test & $60.0 \pm 1.8$ & $62.0 \pm 2.0$ & 0.17 & $<0.04$ \\
\hline
\end{tabular}

Table 4. Dynamics of changes in the level of physical readiness EG

\begin{tabular}{|c|c|c|c|c|}
\hline \multirow{2}{*}{ Indicators } & $\begin{array}{c}\text { At the beginning } \\
\text { of the year }\end{array}$ & $\begin{array}{c}\text { At the end of } \\
\text { the year }\end{array}$ & \multirow{2}{*}{ t1 } & P1 \\
\cline { 2 - 4 } & $\mathrm{X} \pm \mathrm{x}$ & $\mathrm{X} \pm \mathrm{x}$ & & \\
\hline Running 100 meters & $24.8 \pm 0.9$ & $22.9 \pm 0.6$ & 0.078 & $<0.04$ \\
\hline Running 1000meters & $4.54 \pm 0.23$ & $4.12 \pm 0.34$ & 0.61 & $<0.03$ \\
\hline Long jump from the spot & $160.75 \pm 2.2$ & $164.7 \pm 2.2$ & 3.95 & $<0.05$ \\
\hline Harvardstep-test & $64.2 \pm 1.7$ & $69 . .0 \pm 1.6$ & 0.13 & $<0.04$ \\
\hline
\end{tabular}

Table 5. Dynamics of changes in the level of physical readiness of groups

\begin{tabular}{|c|c|c|c|}
\hline & CG1 & CG2 & EG \\
\hline Running 100 meters & -0.83 & 0.7 & 1.8 \\
\hline Running 1000meters & 0.18 & 0.42 & 0.56 \\
\hline Long jump from the spot & 1.8 & 3.95 & 3.95 \\
\hline Harvardstep-test & 1.5 & 2.0 & 4.8 \\
\hline
\end{tabular}

The obtained data allow us to reliably assert that:

- the speed indicators of the comparison group (CG1) have significantly worsened over the past period, in CG2 there is a significantly significant increase $(0.7 \mathrm{~s})$. The use of the author's technique made it possible to reliably increase this indicator in the EG group by $1.8 \mathrm{~s}$;

- the endurance of the CG1 has a slight increase - by 0.18 minutes, while the children exercising in the center Pilgrim CG2 and the EG improved their indices by 0.42 and 0.56 minutes, respectively.

- the dynamics of changes in speed-power abilities (jump from standing to length) speaks of a reliably significant advantage in the growth of the indicator of children exercising 
in the Pilgrim center compared to the comparison group by $2.11 \%(1.8 \mathrm{~cm}$ in $\mathrm{CG} 1$ and $3.95 \mathrm{~cm}$ for $\mathrm{CG} 2$ and $\mathrm{EG}$ ).

- all of the above testifies to the effectiveness of the use of the author's methodology as a factor in improving the somatic and physical health of children aged $10-12$ years.

The results of the study of psychological parameters that determine the influence of the methodology on children involved in sports tourism in the center Pilgrim are presented in tables $6-8$.

Table 6. Influence of the author's methodology on the well-being of participants

\begin{tabular}{|c|c|c|c|c|c|}
\hline \multirow{2}{*}{ Indicators } & \multicolumn{5}{|c|}{ Stages of the pedagogical experiment } \\
\cline { 2 - 6 } & $\begin{array}{c}\text { Number of } \\
\text { children }\end{array}$ & $\begin{array}{c}\text { Initial } \\
X \pm x, \%\end{array}$ & $\begin{array}{c}\text { Final, } \\
X \pm x, \%\end{array}$ & $\mathrm{t}$ & $\mathrm{P}$ \\
\hline CG1 & 12 & $9.15 \pm 0.8$ & $9.4 \pm 1.8$ & 5.88 & $<0.04$ \\
\hline CG2 & 12 & $11.3 \pm 1.2$ & $12.8 \pm 1.6$ & 2.71 & $<0.03$ \\
\hline EG & 12 & $10.8 \pm 1.1$ & $16.52 \pm 2.3$ & 6.75 & $<0.05$ \\
\hline
\end{tabular}

Conclusions: the analysis of Table 6 allows us to state:

- manifestations of the mental state - "well-being" in CG1 does not have any significant changes;

- a similar indicator of the group of children studying in the center Pilgrim in the comparison group CG2 according to the standard method $\nabla \mathrm{X}=1.5$ (the growth was $13.27 \%$ ). In the experimental group $\nabla \mathrm{X}=5.72$ (growth was $52.96 \%$ ).

Table 7. Influence of the author's methodology on the activity of participants.

\begin{tabular}{|c|c|c|c|c|c|}
\hline \multirow{2}{*}{ Indicators } & \multicolumn{5}{|c|}{ Stages of the pedagogical experiment } \\
\cline { 2 - 6 } & $\begin{array}{c}\text { Number of } \\
\text { children }\end{array}$ & $\begin{array}{c}\text { Initial } \\
X \pm x, \%\end{array}$ & $\begin{array}{c}\text { Final, } \\
X \pm x, \%\end{array}$ & $\mathrm{t}$ & $\mathrm{P}$ \\
\hline CG1 & 12 & $12.5 \pm 1.1$ & $12.4 \pm 1.4$ & 4.03 & $<0.05$ \\
\hline CG2 & 12 & $13.3 \pm 1.04$ & $14.2 \pm 2.1$ & 10.2 & $<0.04$ \\
\hline EG & 12 & $12.6 \pm 1.3$ & $15.9 \pm 1.9$ & 9.34 & $<0.05$ \\
\hline
\end{tabular}

Conclusions: the analysis of Table 73 allows us to state:

- at the beginning of the experiment, there are no statistically significant differences in the indicators of all groups $(\nabla \mathrm{X}=<0.8)$;

- manifestations of mental state - "activity" in CG1 does not have any significant changes, there is a slight decrease in activity on the diagram and graph;

- a similar indicator of the group of children studying in the center Pilgrim in the comparison group $\mathrm{CG} 2$ according to the standard method $\nabla \mathrm{X}=0.9$ (the growth was $6.77 \%$ ). In the experimental group $\nabla \mathrm{X}=3.3$ (growth was $26.19 \%$ ).

Table 8. Level of change in mood

\begin{tabular}{|c|c|c|c|c|c|}
\hline \multirow{3}{*}{ Indicators } & \multicolumn{4}{|c|}{ Stages of the pedagogical experiment } \\
\cline { 2 - 5 } & $\begin{array}{c}\text { Number of } \\
\text { children }\end{array}$ & $\begin{array}{c}\text { Initial } \\
X \pm x, \%\end{array}$ & $\begin{array}{c}\text { Final, } \\
X \pm x, \%\end{array}$ & $\mathrm{t}$ & $\mathrm{P}$ \\
\hline
\end{tabular}




\begin{tabular}{|c|c|c|c|c|c|}
\hline CG1 & 12 & $15.2 \pm 2.1$ & $15.0 \pm 1.6$ & 7.09 & $<0.04$ \\
\hline CG2 & 12 & $14.6 \pm 1.8$ & $16.1 \pm 1.9$ & 0.23 & $<0.03$ \\
\hline EG & 12 & $13.9 \pm 2.0$ & $18,7 \pm 2.3$ & 7.92 & $<0.05$ \\
\hline
\end{tabular}

Conclusions: the analysis of Table 8 allows us to state

- at the beginning of the experiment, there are no significantly significant differences in the indicators of the control groups $(\nabla \mathrm{X}=<0.03)$, in the comparison group the similar indicator is lower $(\nabla \mathrm{X}=1.3)$;

- manifestations of mental state - "mood" in CG1 does not have any significant changes, there is a slight decrease in activity on the diagram and graph;

- a similar indicator of the group of children, engaged in the center Pilgrim in the comparison group CG2 according to the standard method $\nabla \mathrm{X}=1.5$ (the growth was $10.7 \%$ ). In the experimental group $\nabla X=4.8$ (growth was $34.53 \%$ ).

\section{Conclusion}

Summarizing the data obtained in the course of the pedagogical experiment, we can conclude that purposeful training in sports tourism using new organizational forms, means and methods provided by the experimental program allows to achieve more significant changes in the level of the studied quality [11].

The use of the author's methodology in the educational and training process of sports tourism as a factor in improving the somatic, mental and physical health of children is confirmed by the results of the study.

\section{References}

1. L. Demyanova, O. Mavropulo, I. Usova, The health-improving and professionally applied aspect of physical culture in the training of agro-industrial complex personnel, XIII International Scientific and Practical Conference "State and Prospects for the Development of Agribusiness - INTERAGROMASH 2020" 175, (2020). doi:10.1051/e3sconf/202017515025.

2. V.S. Merenkova, Sensorimotor Integration and the Inner Picture of Health of the Primary Schoolchildren, International Journal of Psychophysiology Conference. Abstract 3, (2018).

3. Emma V. Sanchez-Vaznaugh, Brisa N. Sánchez Susan Egerter, Physical Education Policy Compliance and Children's Physical Fitness, American Journal of Preventive Medicine 5, 132-139 (2012).

4. A. Osipov, M. Kudryavtsev, P. Fedorova, Zh. Serzhanova, E. Panov, L. Zakharova, A.Savchuk, M. Yanova, Components of positive impact of exposure on university physical culture and sports on students' physical activity, Journal of Physical Education and Sport 17 ( 2), 871-878 (2017). doi:10.7752/jpes.2017.02133.

5. N. Parshikova, S. Izaak, V. Malits, National physical culture and sports sector longterm development strategy, Theory and practice of physical culture 12, 3-5 (2017).

6. O. Blynova, I. Popovych, T. Tkach, I. Serhet, N. Semenova, O. Semenov, Value Attitudes of Student Youth to Physical Culture and Sports as Factors in their Aspiration for Success, Journal of Critical Reviews 7 (19), 6775-6783 (2020). doi: $10.31838 /$ jcr.07.19.778 
7. L.G. Pashchenko, Physical activity and motivation of physical culture and sports of the adult population in Russia and abroad, Bulletin of Nizhnevartovsk Sate University 3, 110-116 (2017).

8. Richard Thomas, Running Through Travel Career Progression: Social Worlds and Active Sport Tourism, Journal of Sport Management 2, 243-248 (2020). doi: 10.1123/jsm.2019-0256.

9. Muammer Pekerşen Mesci, Yeliz Mesci Zeynep, An overall assessment of sports tourism articles, Journal of Hospitality and Tourism Insights. A head-of-print 6, 166172 (2020). doi: 10.1108/JHTI-04-2020-0054.

10. Jennifer Stoll, Anthony Andrew, Sport tourism entity desired outcomes, Journal of Sport \& Tourism 24, 1-19 (2020). doi: 10.1080/14775085.2020.1822201.

11. Joanne Jung-Eun, Active sport event participants' behavioural intentions: Leveraging outcomes for future attendance and visitation, Journal of Vacation Marketing 27, 274280 (2020). doi: 10.1177/1356766720948249. 